\title{
Decision-Maker and Context Effects in Employment Arbitration
}

\author{
Mark Gough and Alexander Colvin
}

\begin{abstract}
Using a novel survey of 284 employment arbitrators, this study investigates how decision-maker characteristics and the context of the arbitration proceeding affect employee outcomes. We analyze the predictors of settlement before an arbitrator award and, if no settlement is reached, the likelihood an employee will receive a verdict in their favor after a full hearing. We find pre-arbitration dispute resolution procedures have significant effects on settlement behavior and employee outcomes. The characteristics of the presiding arbitrator as well as the structure of the arbitration proceeding were also found to affect employee outcomes at trial. This study contributes to the existing literature by describing characteristics of employment arbitrators, an underexplored actor in industrial relations, and analyzing case outcomes, including settlements, across multiple arbitration forums and with more rigorous controls than have been available in existing datasets.
\end{abstract}


Introduction

The rise of employment arbitration represents a major transformation in the landscape of American workplace dispute resolution. Although debates have been intense over the adoption of arbitration procedures covering statutory employment rights as mandatory terms and conditions of employment, such procedures are legally well established and an increasingly common feature of the American workplace, covering a quarter or more of all employees (Colvin, 2007). The value of arbitration as an alternative dispute resolution (ADR) procedure is premised on the idea that conflict resolution can be enhanced by transferring to a third party neutral the authority to decide the outcome of the case. Arbitration laws seek to support its effectiveness by ensuring that contracts agreeing to arbitration are liberally enforced without intrusive oversight by the courts and that the arbitrator's decision-making is insulated from judicial review. This vision of the autonomous arbitrator dispensing justice to the satisfaction of the parties to the dispute is an attractive one, but obscures important questions of who the arbitrators are who decide the cases and what is the institutional and organization structure supporting arbitration. In this paper, we examine these questions in relation to the important and controversial area of arbitration of individual employment rights disputes.

This research is motivated by two concerns. First, to illuminate characteristics of employment arbitrators, a relatively nascent and underexplored profession (Seeber \& Lipsky, 2006). Second, to explore how arbitrator characteristics and the institutional context of the arbitration proceeding itself influence the trajectory and outcome of employment arbitration cases. 
Employment arbitrators wield significant power to interpret statutory law determined at the local, state, and federal level, which until recently was the exclusive domain of public courts and administrative agencies. Research on employment arbitration has examined important issues relating to its legal status, due process protections, and the outcomes of cases (e.g. Stone 1996, Bingham 1998, Sherwyn et al 2005, Colvin 2007, 2011, Lipsky et al 2013, Colvin and Gough 2015). However research on the employment arbitrators who are deciding the cases has been much more limited. A notable exception is the work of Seeber and Lipsky (2006) who examined the question of whether employment arbitrators have begun to take on the characteristics of a profession. Their conclusion was that while employment arbitrators had begun to assume the role of important actors in the employment relations system, they had not yet developed the traditional indicia of a profession, such as professional training, certification, and associations or even full-time employment in the profession. However their analysis was limited by the lack of systematic data on the characteristics or practices of employment arbitrators. It is also unknown whether their conclusions would continue to hold now, over a decade later, given the subsequent growth and greater usage of arbitration. In this study, we pick up Seeber and Lipsky's call for greater attention to employment arbitrators as actors in the employment relations system and examine the characteristics of this emergent profession.

Our analysis is based on data from an original survey of 284 practicing employment arbitrators conducted in 2015. In addition to the personal characteristics of employment arbitrators, we investigate the organizational and institutional structure within which they are arbitrating cases. Although the ideal vision of arbitration may picture an autonomous neutral operating completely independently, in reality arbitrators operate within an institutional and organizational structure 
that shapes the cases that reach arbitration and what happens in the arbitral forum. The institutional structure of arbitration includes the nature of the agreement that led to arbitration, such as whether it was individually negotiated or part of a mandatory arbitration procedure promulgated by an employer for all of its employees. The organizational structure of arbitration includes whether there is an arbitration service provider administering the case or if it is being handled by the arbitrator him or herself on an ad hoc basis. In addition, the cases that reach arbitration will be influenced by other ADR procedures that may occur prior to arbitration, including international organizational grievance procedures and attempts to mediate the case. All of these factors will shape what cases are heard in arbitration and what happens to those cases that do reach arbitration.

\section{Literature Review}

Traditional models of judicial decision making assert judges decide cases in predictable ways based on rigid adherence to the objective facts of a case, the black letter of the law, and judicial precedent (Segal and Spaeth, 2002; Nielson et al, 2010; Edelman et al, 2011). In such a formal legal model arbitrators are a monolithic force applying the relevant law to the facts presented without personal biases, interpretation, or regard to the economic, social, or organizational context of the case. This formal legal model has long been viewed with skepticism and scholars have increasingly begun to develop more nuanced theories of judicial decision making (Scott and Shadoan, 1989; Spaeth and Segal, 1999; Steffensmeier and Herbet, 1999; Guthrie et al, 2007). 
Legal sociologists posit determination of whether there has been a violation of employment rights is socially constructed through a process embedded in a larger environments (Edelman et al, 1999; Hirsh and Kornrich, 2008). This analysis has been used to help understand the behavior of regulatory agents such as the EEOC and also the judiciary and can be applied in the context of arbitration (Edelman, 1992; Edelman et al, 1999; Hirsh and Kornrich, 2008). If a questionable employment action is raised by an employee in arbitration, it will not be perceived in a vacuum; rather, arbitrators should view the action within the broader context of their own experiences and characteristics of the case.

Do the professional backgrounds and personal characteristics of arbitrators affect employee outcomes? We explore this question by analyzing whether experience as a labor arbitrator, past employment as defense counsel, and gender affect arbitrator decision-making.

\section{Professional Experiences and Demographics}

While employment arbitration is a relatively new profession, there is a long-standing system of labor arbitration used to resolve disputes in unionized workplaces. The cadre of professional neutral labor arbitrators has won a well-deserved reputation for respect for due process and fairness in decision-making. Some of these same labor arbitrators are now among the arbitrators deciding employment cases in mandatory arbitration proceedings. Do labor arbitrators who also practice employment arbitration differ in their decision-making from other employment arbitrators? 
The cumulative decisions and professional norms built over the past 75 years have given labor arbitrators a far-reaching and unique role in industrial relations. A labor arbitrator's broad authority is predicated on the view that collective bargaining agreements are imperfect, or at least incomplete, charters for enforcing the "common law of the shop." Rather than interpreting collective bargaining agreements with a rigid adherence to the black letter of the text, decisions are rendered to comport with basic standards of due process and unwritten rules, practices, and customs. Notions of just cause, progressive discipline, and the allocation of the burden of proof are routine components of labor arbitrator decision-making. Professional labor arbitrators acting in an employment arbitrator capacity may transpose some of these decision-making principles from labor arbitration into the employment arbitration setting, resulting in more employeefavorable outcomes.

We investigate the potential impact of this type of professional background and status to affect arbitration outcomes by looking at the effect of arbitrator membership in the National Academy of Arbitrators (NAA), the leading professional organization of prominent labor arbitrators. Membership in the NAA is a prestigious credential desired by arbitrators, reflecting a leading position in the profession. Membership requires substantial experience as an impartial arbitrator of labor-management disputes: at least five years of experience and a minimum of 60 written decisions over a six-year period (National Academy of Arbitrators 2012).

In an analysis of almost 3,000 employment arbitration decisions administered by the AAA over an 11-year period, Colvin and Gough (2015) find that NAA membership is associated with lower employee win rates and award amounts in arbitration. Unable to establish causation, they posit 
this relationship may result from labor arbitrators being selected in systematically weaker cases rather than innate differences in decision making. However, using a policy-capturing study, Klaas et al (2006), compared decisions made in hypothetical termination cases by 140 AAA employment arbitrators, 82 labor arbitrators from the National Academy of Arbitrators (NAA), and 83 former employment discrimination case jurors. The study found that labor arbitrators were more likely to rule in favor of the employee than employment arbitrators in this experimental setting. Bingham and Mesch (2003) report decisions of employment arbitrators in a hypothetical discharge case were less employee-favorable compared to labor arbitrators in an experimental study. These experimental studies suggest there are differences in the decisionmaking of labor and employment arbitrators.

As professional experience as a labor arbitrator may influence the direction of employment arbitrator decisions, so too should a background as a defense attorney, i.e. having represented employers in employment law cases. Bonica et al (2016) explore the ideology of lawyers and find that defense attorneys, including those who practice in the labor and employment law area, are more politically conservative than lawyers from other practice areas. While Bonica et al (2016) do not directly measure the effect of political background on decisionmaking, it provides a useful bridge to the plethora of studies establishing a relationship between political preferences and judicial behavior. Indeed, a meta-analysis of over 80 studies examining the relationship between political ideologies and judicial decision-making found that a judge's political leanings has large effects on the directions of decisions (Pinello, 1999). In addition to political ideologies, decision-making differences are likely to manifest as a result of career socialization effects. Those with experience as defense attorneys are likely to have spent their 
time defending the position of the "haves" against the claims of the "have nots," which may result in more conservative rulings in their new role as arbitrators (Tate, 1981). Taken together, we would expect arbitrators having professional backgrounds as defense counsel to be associated with more business friendly (or employee unfriendly) decisions.

Numerous studies have empirically tested what effect, if any, gender has on decisionmaking in dispute resolution forums. In the realm of labor arbitration, a number of studies have examined the effect of gender, with mixed results. Zirkel (1983), looking at 369 labor arbitration decision, and Bigoness and Dubose (1985), using 80 students as mock arbitrators, found no difference between decisions of male and female arbitrators. Scott and Shadoan (1989) tested to see if female arbitrators issue less severe judgments than male arbitrators, but their empirical findings failed to identify any significant differences between the genders. In analyzing 177 arbitrators rulings on six hypothetical cases, Thorton and Zerkil (1990) also found that arbitrator gender cannot account for any differences in the awards granted to grievants. By contrast, Bemmels (1990) found that women arbitrators issued judgments slightly more favorable to grievants than male arbitrators in a sample of 2,001 labor arbitration awards. And Block and Stieber (1987) found that male arbitrators issued longer suspensions relative to female arbitrators. On the other hand, Caudill and Oswald (1993) asked 146 arbitrators to rule on a hypothetical drug-testing case and found that women arbitrators are harsher than their male counterparts. They found that women arbitrators were less likely to issue full reinstatements, but also found that gender did not have explanatory power in length of suspensions. 
In the employment arbitration setting, Lipsky, Lamare, and Gupta (2013) found that, in securities industry employment arbitrations administered by the Financial Industry Regulatory Authority (FINRA), female arbitrators awarded larger amounts than male arbitrators in a simple bivariate comparison, but there was no significant difference once control variables were added to the model. As Lipsky et al. (2013) note, however, their results may be influenced by the specific industry setting of the securities industry in which FINRA arbitrations occur. A further analysis of the FINRA data published by Lamare and Lipsky (2014) did not find a significant relationship between arbitrator gender and employee outcomes. Outside of the financial services industry, Colvin and Gough (2015) report male arbitrators are associated with higher levels of settlement before final adjudication and more likely to render awards in favor of employees, though the latter effect was only marginally significant.

\section{Context of Arbitration}

Internal ADR procedure

Prior research suggests that factors such the presence of affirmative action plans, equal employment opportunity policies, and formal dispute resolution procedures may influence arbitrator valuation of cases. Because formalized dispute resolution policies require adherence to published objective criteria, increased formalization should protect against illegal considerations, such as race or sex, in employment decisions (Pfeffer, 1977). The presence of formalized dispute resolution policies should signal to arbitrators that workplace decisions are free from improper considerations, making them less likely to rule in favor of plaintiffs with employment claims. There is no statutory requirement that employers establish internal dispute resolution programs, yet Edelman (2002) reports that courts frequently cite the mere existence of internal 
dispute resolution channels as evidence against the inference of discrimination. Further, Hirsh and Kornrich (2008) show that EEOC officials view the presence of affirmative action plans as evidence of employer compliance with EEO laws, regardless of the actual gender and racial composition of the workplace. Therefore, we expect the presence of an internal grievance procedure to be negatively associated with employee win rates.

Use of a firm's internal dispute resolution procedure may also influence outcomes in arbitration by influencing the type and underlying merits of cases proceeding to arbitration. Internal dispute resolution procedures are designed, in part, to obviate the need to seek remedies in court or other venues outside the firm (Colvin, 2007). By providing procedural justice and an alternative dispute resolution forum, meritorious disputes are likely to be resolved without escalating the claim and resorting to litigation or arbitration. If use of internal dispute resolution procedures filters out meritorious claims prior to arbitration, we would expect claims that continue to arbitration to be less meritorious, on average, and, therefore, associated with lower employee win rates. Further, employees and employers who have progressed through an internal dispute resolution process have presumably had numerous failed opportunities to settle their claims; therefore, we expect settlement rates to be negatively associated with prior experience with internal dispute resolution procedures.

Mandatory v. Individually-negotiated agreements

Mandatory arbitration contracts have been criticized as the yellow dog contracts of the twenty first century (Stone, 1996). Just like yellow dog contracts restricting employees’ rights to union membership, many mandatory arbitration contracts are unilaterally imposed on employees as 
contracts of adhesion. Appearing in employee handbook or presented in a separate document at the time of hire, mandatory arbitration agreements are imposed without the illusion of discussion and in the absence of employee bargaining power. By definition, mandatory arbitration agreements foreclose employee access to civil court and the $7^{\text {th }}$ amendment right to trial by jury and may limit other procedural protections offered by civil courts. For example, the Supreme Court provided an additional incentive for employers to use mandatory arbitration in its 2012 decision in AT\&T v. Concepcion, 489 U.S. 468 (2012), holding that a class action waiver in an arbitration agreement could require that any claim had to be brought individually. Thus mandatory arbitration agreements with class waivers can now effectively employees from bringing class actions in either arbitration or litigation. Where arbitration clauses are imposed on employees as mandatory contracts of adhesion, we predict lower levels of due process protection than if arbitration causes are individually-negotiated or voluntarily accepted by employee claimants.

\section{Ad Hoc Cases}

The context in which the employment arbitration occurs is also likely to affect employee outcomes. Whether an arbitration proceeding occurs under the aegis of an established arbitration provider such as the American Arbitration Association (AAA) and JAMS or is merely specified ad hoc affects due process guarantees. Specifically, established arbitration providers have adopted the Due Process Protocol for Mediation and Arbitration of Statutory Disputes Arising Out of the Employment Relationship (Due Process Protocol). The Due Process Protocol was established in 1995, “in order to assure some measure of fairness and due process to employer- 
promulgated schemes for private resolution of statutory disputes” (American Bar Association, 1995). The Due Process Protocol recommends specific features and processes that should be present in arbitration agreements and hearings including (1) freedom of representative choice; (2) adequate prehearing discovery; and (3) joint selection and compensation of the arbitrator, among others. It was supported and endorsed by multiple organizations including the National Academy of Arbitrations, American Arbitration Association, Society of Professionals in Dispute Resolution, National Employment Lawyers Association, Federal Mediation and Conciliation Service, and the American Civil Liberties Union, and is now the standard. Theoretically, the adoption of the Due Process Protocol should make the arbitration process more friendly and fair to employees, and employee win rates, ceteris paribus, should be higher when proceeding under the rules of established providers relative to proceedings occurring ad hoc.

\section{Pro Se Representation}

Attorney assistance is essential when trying to assert or defend against complex employment law and the equally complex rules of legal institutions (Sandefur, 2015). Many proponents claim that the relative expediency and informality of employment arbitration creates a more accessible forum for parties without representation (Estreicher, 2001). However, studies have shown that employees attempting to navigate the legal process on their own without attorney representation, known as pro se, experience lower settlement rates and win rates in both arbitration (Colvin, 2011; Colvin and Gough, 2015) and litigation (Schwab and Eisenberg, 1988; Clermont and Schwab, 2004, 2009; Nielsen et al, 2010). 
Data and Methods

Data

The survey frame consisted of active employment arbitrators from the National Academy of Arbitrators (NAA), American Arbitration Association (AAA) and JAMS (Formerly Judicial Arbitration and Mediation Services, Inc.) compiled from the agencies’ case reports and rosters. JAMS and AAA are the largest arbitration providers in the U.S. and are jointly responsible for administering a majority — approximately 70\% — of all employment arbitrations in the country (Gough \& Colvin, 2015). Pursuant to state law, arbitration providers are required to report key information on all mandatory consumer arbitration conducted, including arbitrator names. We were able to produce the universe of practicing AAA and JAMS employment arbitrators from these disclosures. Also included in the survey frame are NAA members, allowing us to assess the current state of employment arbitration practice among the Academy's membership, as well as being able to identify differences between employment and labor arbitrators. In total, our survey sampling frame consisted of 1,117 unique arbitrators.

We administered the survey questionnaire during Winter and Spring of 2015 using a combined web-based and physical mailing method. For the web-based administration, arbitrators received an initial email requesting their participation with a link to the web-based survey instrument, as well as two follow-up reminders. We then mailed paper copies of the survey to non-respondents to solicit additional participation. This combination of web-based and traditional hard-copy mailing yielded 497 useable responses from practicing arbitrators, representing a response rate of 
44 percent. However, of the 497 total responses, only a subset of 284 arbitrators had experience with employment arbitration and are considered in the analysis that follows. ${ }^{1}$

We asked employment arbitrators to record the following information relating to their most recently disposed employment arbitration case: mode of disposition and the verdict, if awarded; arbitrator characteristics, including demographic information, experience as a labor arbitrator, and work history; the structure of the arbitration proceeding including whether the an internal grievance procedure was used before arbitration, whether mediation was attempted, whether the case was administered by an established arbitration provider, whether the proceeding was engendered by a mandatory arbitration clause or was individually-negotiated, and whether the employee or employer proceeded without the use of an attorney; and numerous controls for case characteristics. Instrument pre-testing confirmed arbitrators were able to accurately interpret and respond to these inquiries.

These data afford a unique sample of arbitration claims across multiple arbitration providers and detailed case information that builds off prior research analyzing information from limited disclosure statements (Colvin, 2011; Colvin \& Gough, 2015; Lamare \& Lipsky, 2014; Lipsky, Lamare, Gupta, 2013). Importantly, the introduction of more robust controls helps to account for the endogeneity found in most of the above field studies. Further, while previous experimental studies provide insights into arbitral decision-making and are high in internal validity, it is important to analyze the reality of arbitrator decision-making in the field.

\footnotetext{
${ }^{1}$ The excluded respondents practiced labor arbitration exclusively and, therefore, were outside the scope of this analysis.
} 


\section{Research Methodology}

Dependent Variables

We analyze two dependent variables representing (1) early disposition via settlements and (2) employee wins at trial. We focus on settlement behavior in arbitration for several reasons. First, the focus of extant studies, with few exceptions, is trained on distributive outcomes-win rates and award amounts — after an arbitrator award. While crucial to understanding the institution of employment arbitration, analyzing settlement behavior sheds light on the most common disposition in arbitration (Colvin \& Gough, 2015). Further, settlements prior to final adjudication directly affect the stock of cases appearing before the arbitrator at the terminal step. In this study, the binary variable Settlement is coded as 1 if a case was voluntarily settled by the parties prior to an adjudication and 0 if the case terminated in an arbitrator award. Of the 260 reported employment arbitration cases, a total of 72, or 28 percent, were settled prior to adjudication. The remaining 188 cases were disposed by an arbitrator award after a full hearing. 188 arbitrated observations may not be large in an absolute sense; however, it represents a substantial portion of the total number of cases arbitrated on a yearly basis. ${ }^{2}$

The second dependent variable we analyze measures employee success after a full arbitration hearing. Arbitrators reported whether the final disposition in their recent case was a verdict in favor of the employee, either in part or in full, or a verdict in favor of the employer. Employee Win is coded as 0 if arbitrators reported a verdict in favor of the employer and 1 if they reported a verdict in favor of the employee. Employees won 83, or 43 percent, of the 188 awarded cases reported by arbitrators.

\footnotetext{
${ }^{2}$ For example, the largest arbitration provider in the country, the American Arbitration Association, reports just under 300 cases a year that are adjudicated by an arbitrator.
} 
Independent Variables

Arbitrator Characteristics

Arbitrators self-reported their gender, National Academy of Arbitrator affiliation, and prior work history as management-side defense counsel. Female Arbitrator ( $1=$ female, $0=$ male), denotes arbitrator gender. Only one-quarter, or precisely 27 percent, of arbitrators in the sample are female. Female arbitrator represent 28 percent of the sample of awarded cases, or 52 out of 188. The variable NAA Member is coded as 1 if the arbitrator maintains a labor arbitrator practice and appears on the National Academy of Arbitrator roster and 0 otherwise. Thirty-five percent of the sample of arbitrators maintain NAA membership and NAA members represent 30 percent of awarded cases. Defense Counsel Background is another binary variable coded as 1 if an arbitrator reported previous experience as management-side defense counsel and 0 otherwise. Slightly over half, or 51 percent, of arbitrators have experience working as management-side defense counsel.

\section{Structure and Context of Arbitration}

The study contains dichotomous controls for six additional independent variables. Internal Grievance Procedure indicates whether an internal grievance procedure was used prior to the case being filed in arbitration. Just over half of the cases, or 51 percent, used an internal grievance procedure prior to arbitration. Mediation is coded as 1 where mediation was attempted after the case was filed in arbitration and 0 if no mediation occurred. Approximately one-fifth of cases in the sample progressed through mediation prior to final adjudication by an arbitrator. Ad Hoc Case is coded as 1 if the arbitrator was appointed outside the auspices of an arbitration 
provider and 0 if the arbitrator was appointed from a roster provided by an arbitration agency.

As described in Appendix 2, the majority of cases in the sample were overseen by the American Arbitration Association, JAMS, a standing panel, or court referral; 20 percent of cases proceeded on an ad hoc basis. Mandatory Arbitration denotes whether the case proceeded pursuant to a mandatory arbitration clause (Mandatory Arbitration $=1$ ) or an arbitration clause that was individually- or voluntarily-negotiated (Mandatory Arbitration = 0). 70 percent of the cases described involved mandatory arbitration clauses while the remaining 30 percent proceeded under voluntary arbitration agreements. Finally, Employee Self-Represented and Employer SelfRepresent are binary variables indicating whether the parties to the arbitration represented themselves pro se. Six percent of cases involved employers that represented themselves and 14 percent involved cases where employees were represented pro se.

\section{Controls}

In additional to the main independent variables, we control for plaintiff gender, plaintiff underrepresented racial minority status, plaintiff salary, the size of the employer defendant, and the basis for individual claims. ${ }^{3}$ See Appendix 1 for additional detail.

\footnotetext{
${ }^{3}$ Case basis can be broken down into cases alleging violations of the Family Medical Leave Act (FMLA), Occupational Safety and Health Act (OSHA), Anti-Discrimination Statutes, Torts, Contractual violations, Retaliation, and Wage and Hour Violations. Cases can allege multiple bases. See Appendix 1 for more detail.
} 


\section{Results - Arbitrator Demographics and Career Backgrounds}

We begin by looking at the demographics and professional backgrounds of the employment arbitration profession. Table One reports demographic characteristics and career backgrounds of survey respondents.

\begin{tabular}{|l|l|}
\hline Employment Arbitrator Summary Statistics & Distribution \\
\hline Variable Name & 260 \\
\hline Sample Size (N) & $27 \%$ \\
\hline Sex (Female) & $10 \%$ \\
\hline Race (Non-White) & $97 \%$ \\
\hline Terminal Degree (JD or PhD) & $46 \%$ \\
\hline Part-Time Neutral & $35 \%$ \\
\hline NAA Member & $61 \%$ \\
\hline Defense Counsel Background & $16(16)$ \\
\hline Years of Employment Arbitrator Experience (mean (median)) & $\$ 375(\$ 375)$ \\
\hline Average Hourly Rate (mean (median)) & \\
\hline
\end{tabular}

One of the long-standing concerns in the arbitration profession is a lack of demographic diversity among arbitrators. We find that employment arbitrators are predominantly male and non- 
Hispanic white. The vast majority of arbitrators hold advanced degrees, either J.D.'s or Ph.D.'s. Arbitrators hail from the Midwest (37\%), Northeast (25\%), West (16\%), Southeast (13\%), Southwest (7\%), and Canada (2\%). Just over half (54\%) of employment arbitrators are full-time neutrals. What other work do the arbitrators who are part-time neutrals do? Most of the employment arbitrators who are part-time neutrals are practicing attorneys in their other work. The practicing attorneys who are part-time neutrals are just over twice as likely to represent employers (61\%) as to represent employees (30\%) in their legal practices. Arbitrators had, on average, 16 years of experience and charged an average hourly rate of $\$ 375$.

The simultaneous influences of the above variables on settlement behavior and employee win rates are modeled in Table 1 below. As both settlement behavior and employee wins are measured as dichotomous variables, we employ logit regressions in Model 1 and Model 2. 
Table 1: Regression Results

\begin{tabular}{|c|c|c|c|c|}
\hline & \multirow{2}{*}{\multicolumn{2}{|c|}{$\begin{array}{c}\text { Model 1: Settlement } \\
\text { (Logit) }\end{array}$}} & \multirow{2}{*}{\multicolumn{2}{|c|}{$\begin{array}{c}\text { Model 2: Employee Win } \\
\text { (Logit) }\end{array}$}} \\
\hline & & & & \\
\hline & Odds Ratio & Robust S.E. & Odds Ratio & Robust S.E. \\
\hline \multicolumn{5}{|l|}{ Arbitrator Characteristics } \\
\hline NAA Member & 0.93 & 0.45 & $0.44+$ & 0.21 \\
\hline Defense Counsel Background & 1.06 & 0.35 & $0.40^{*}$ & 0.17 \\
\hline Part-Time Status & 0.96 & 0.37 & 0.705 & 0.32 \\
\hline Female Arbitrator & 0.56 & 0.21 & 0.47 & 0.24 \\
\hline \multicolumn{5}{|l|}{ Pre-arbitration ADR } \\
\hline Internal Grievance Procedure & $0.37 *$ & 0.13 & $0.37 *$ & 0.15 \\
\hline Mediation & $2.81^{* * *}$ & 1.06 & 1.28 & 0.73 \\
\hline \multicolumn{5}{|l|}{ Structure of Arbitration } \\
\hline Ad Hoc Appointment & 0.88 & 0.40 & 1.06 & 0.59 \\
\hline Mandatory Arbitration Clause & 1.54 & 0.66 & $0.30 *$ & 0.16 \\
\hline Employee Self Represented & 0.95 & 0.56 & $0.06 *$ & 0.06 \\
\hline Employer Self Represented & - & - & $60.34^{* *}$ & 78.60 \\
\hline Full Controls & YES & & YES & \\
\hline Constant & 0.228 & & 1.496 & \\
\hline Psuedo R-squared & 0.1978 & & 0.3165 & \\
\hline $\mathrm{N}$ & 260 & & 188 & \\
\hline
\end{tabular}

Within category differences significance levels: $+\mathrm{p}<.10 ; * \mathrm{p}<.05 ; * * \mathrm{p}<.01 .{ }^{* * *}<.001$.

Note: All regressions control for plaintiff gender, plaintiff race, plaintiff salary, size of defendant firm, and legal basis for case. 
Model 1 tests the effects our independent variables have on the odds a case will settle prior to arbitrator adjudication. The coefficient (B) reported in Model 1 imply that for every unit increase in an independent variable, the odds that a case will settle will be multiplied by $\mathrm{e}^{\wedge} \mathrm{B}$. This transformation is presented as the odds ratio. For example, if the case involves an employment arbitrator who is a member of the national academy of arbitrators with labor arbitration experience, the odds a case will settle are multiplied by $\mathrm{e}^{\wedge}-0.099=0.93$. In other words, if an employee is self-represented, the odds the case will settle prior to adjudication decreases by 7 percent. ${ }^{4}$ However, this is not a statistically significant difference. Likewise, arbitrator characteristics and the structure of arbitration do not have a significant effect on settlement behavior. Significant variables in Model 1 include Mediation and Internal Grievance Procedure. If the arbitration case was filed after progressing through an internal grievance procedure, the odds of settlement decrease by 67 percent. This effect is significant below the .05 level. The use of mediation prior to arbitration is significant at the $\mathrm{p}<.001$ level and is associated with a 181 percent increase in the odds of settlement.

Model 2 tests the effect arbitrator characteristics, pre-arbitration ADR, and the structure of arbitration have on the odds employees will win their case. If the presiding arbitrator is a member of the NAA, there is a marginally significant negative effect $(\mathrm{p}<0.10)$ on employee win rates. Specifically, NAA membership is associated with a 56 percent decrease in the odds of an employee win. Likewise, arbitrator experience as management-side defense counsel is significantly $(\mathrm{p}<0.05)$ negatively related to employee win rates. The odds of an employee win decrease by 60 percent when arbitrators have previously worked as defense counsel. No

${ }^{4}(0.93-1) * 100=-7 \%$. 
significant relationship is observed between arbitrator gender and employee win rates. Taken together, these results suggest arbitrator characteristics influence decision-making and employee access to justice in arbitration.

Several variables measuring the context of the arbitration proceeding are significant in Model 2. Internal Grievance Procedure is significant at the $\mathrm{p}<0.05$ level and indicates, where a case has proceeded through an internal grievance procedure prior to initiating arbitration, the odds of an employee win decrease by 67 percent. Where a mandatory arbitration clause, as opposed to a voluntary or individually-negotiated agreement, engendered the arbitration proceeding, the odds of an employee win decrease 70 percent. The coefficient for Mandatory Arbitration Clause is significant at the $\mathrm{p}<0.05$ level. Both Employee and Employer Self-Represented are statistically significant at the $\mathrm{p}<0.05$ and $\mathrm{p}<0.01$ level, respectively. Employees who represent themselves pro se experience a 94 percent decrease in the odds of winning. However, where employees are faced with a defendant employer representing itself without attorney representation, the odds of an employee win increase substantially. However, as can be observed in Appendix 1, we wish to acknowledge the small number of cases where employers are represented pro se and admonish against extrapolating from a sample of this size.

\section{Discussion}

At the outset, we noted the paucity of empirical information about employment arbitrators as a profession and as dispute resolution actors in the employment relations system. The results of our data analysis allow us to draw a picture of the characteristics of this emerging profession and its role in employment dispute resolution. 
Starting with the basic demographics of the profession, employment arbitrators are slightly more diverse than the NAA membership, but are similar in that the large majority of employment arbitrators are white, non-Hispanic males. If the profession is to be more representative of the population of employees who appear before it, then it is important that efforts be made to encourage greater diversity in the ranks of employment arbitrators.

Employment arbitrators continue to be a group that has only partially developed the traditional characteristics of a profession. Although half of the employment arbitrators that we surveyed are full-time professional neutrals, the other half only arbitrate part-time and maintain other careers, mostly as advocates. Employment arbitrators mostly have educational and professional backgrounds as lawyers, suggesting that the occupation is to some degree a sub-section of the legal profession.

Among our most striking findings is the preponderance among employment arbitrators of professional backgrounds or current careers representing employers. Over half of employment arbitrators have worked as defense counsel representing employers and among part-time arbitrators around twice as many represent employers as represent employees in their other employment. One should not automatically assume that simply because an arbitrator has a background representing employers that he or she will be biased against employees when acting as an arbitrators. However our empirical analysis finds that arbitrators who have professional backgrounds as defense counsel are significantly less likely than other arbitrators to decide cases in favor of employees. This finding suggests that the imbalance in professional backgrounds of employment arbitrators is producing a structural imbalance in arbitral decision-making, 
undermining the assumption of third-party neutrality that undergirds the public policy rationale for supporting arbitration. If employment arbitration is to be viewed as a neutral profession, then it is important that greater efforts be made to achieve balanced representation from both sides of the employment relationship.

In addition to investigating the impact of the professional background of the arbitrators, we were also able to look at how the institutional and organizational structure of arbitration affected the outcomes. Mandatory arbitration has been the subject of much controversy and public policy debate. Our results indicate that there are distinctive aspects of mandatory arbitration clauses that make this method of entering into arbitration worthy of greater scrutiny. Compared to cases that were the result of individually negotiated or voluntary arbitration agreements, cases resulting from mandatory arbitration agreements were significantly less likely to be won by employees. This suggests that the controversy over and greater scrutiny of mandatory arbitration agreements is well justified. Conversely, though, it is also a good reminder that the critiques of mandatory arbitration should not be automatically generalized to become critiques of employment arbitration occurring voluntarily or as a result of individually negotiated agreements. Our findings suggests that the structure of arbitration matters, which also implies that arbitration may have a worthy role to play where it is established under appropriate structures.

A long-standing concern surrounding the use of mediation in a dispute resolution process is that mediation will reduce the parties willingness to settle disputes on their own and lead to overreliance on mediation to produce settlement. Our results show that the use of mediation prior to arbitration significantly increased the likelihood of settlement by the parties during the 
arbitration process before the arbitrator had reached a decision. This suggests that having gone through mediation lays the groundwork for subsequent negotiated settlements after the mediation process.

We were also able to investigate the impact of pre-arbitration ADR procedures on the mix of cases that go to arbitration and the resulting outcomes of these arbitration cases. There has been much discussion of the possibility of an appellate effect from internal grievance procedures which might filter out stronger cases by resolving them before they reached arbitration. The best previous evidence of this type effect was only indirect - Colvin’s (2003) analysis showing that internal grievance procedures operating prior to arbitration had increased likelihoods of employees winning and resolving their cases before they could reach arbitration. By contrast, our results here are able to more directly test the appellate effect and show that employees are less likely to win arbitration cases where the case had gone through an internal grievance procedure before arbitration - indicating that these procedures appear to be screening out the stronger cases more likely to produce employee wins.

\section{Conclusion}

Arbitration has often in the past been discussed as a type of generic ADR procedure, with a focus on arbitrating as a process of decision-making. By contrast, in our analysis we have sought to investigate employment arbitration from an employment relations perspective, focusing on the role of key actors in the system and the role of the institutional and organizational structure within which arbitral decision-making operates. Our results indicate that these characteristics of 
the employment arbitration system exert effects on its outcomes. They also point to areas of concern for arbitration policy and possible avenues for reform. Our findings of imbalances in the professional backgrounds of arbitrators that affect the outcomes of case indicates the need for greater balance between employer and employee side backgrounds in the cadre of professional employment arbitrators. Our findings reinforce the need for policy debates to focus on the concerns about mandatory arbitration, while suggesting that other types of employment arbitration should not be automatically swept up in any remedy addressing the structure of mandatory arbitration. Our results also support the use of internal grievance procedures by organizations to resolve employment disputes in the workplace. In general, our analysis reinforces that even in the realm of new forms of employment conflict resolution, the old labor relations adage holds that institutions and institutional design matters. 
Appendix 1: Bivariate Statistics

\begin{tabular}{|c|c|c|c|}
\hline \multirow[b]{2}{*}{ Overall } & Distribution & $\begin{array}{l}\text { Settlement } \\
\text { Rate }\end{array}$ & $\begin{array}{c}\text { Employee Win } \\
\text { Rate }\end{array}$ \\
\hline & $100 \%$ & $26 \%$ & $43 \%$ \\
\hline \multicolumn{4}{|l|}{ Arbitrator Characteristics } \\
\hline NAA Member & $35 \%$ & $19 \%$ & $27 \%$ \\
\hline Defense Counsel Background & $51 \%$ & $27 \%$ & $39 \%$ \\
\hline Female Arbitrator & $27 \%$ & $25 \%$ & $29 \%$ \\
\hline \multicolumn{4}{|l|}{ Pre-arbitration ADR } \\
\hline Internal Grievance Procedure Used & $42 \%$ & $18 \%$ & $30 \%$ \\
\hline Mediation Attempted & $24 \%$ & $38 \%$ & $47 \%$ \\
\hline \multicolumn{4}{|l|}{ Structure of Arbitration } \\
\hline Ad Hoc Case & $22 \%$ & $21 \%$ & $46 \%$ \\
\hline Mandatory Arbitration Clause & $73 \%$ & $28 \%$ & $35 \%$ \\
\hline Employee Self-Represented & $10 \%$ & $12 \%$ & $19 \%$ \\
\hline Employer Self-Represented & $6 \%$ & $0 \%$ & $58 \%$ \\
\hline \multicolumn{4}{|l|}{ Full Controls } \\
\hline Male Plaintiff & $53 \%$ & $26 \%$ & $48 \%$ \\
\hline Minority Plaintiff & $41 \%$ & $31 \%$ & $44 \%$ \\
\hline High-Salary (>\$250k) & $34 \%$ & $18 \%$ & $62 \%$ \\
\hline Large Defendant Firm (>10k employees) & $23 \%$ & $8 \%$ & $47 \%$ \\
\hline Basis: FMLA & $5 \%$ & $42 \%$ & $63 \%$ \\
\hline Basis: OSHA & $1 \%$ & $0 \%$ & $50 \%$ \\
\hline Basis: Discrimination & $48 \%$ & $34 \%$ & $47 \%$ \\
\hline Basis: Tort & $14 \%$ & $17 \%$ & $52 \%$ \\
\hline Basis: Contract & $43 \%$ & $24 \%$ & $45 \%$ \\
\hline Basis: Retaliation & $18 \%$ & $23 \%$ & $51 \%$ \\
\hline Basis: Wage and Hour & $12 \%$ & $19 \%$ & $60 \%$ \\
\hline
\end{tabular}


Appendix 2: Arbitrator Appointment Method

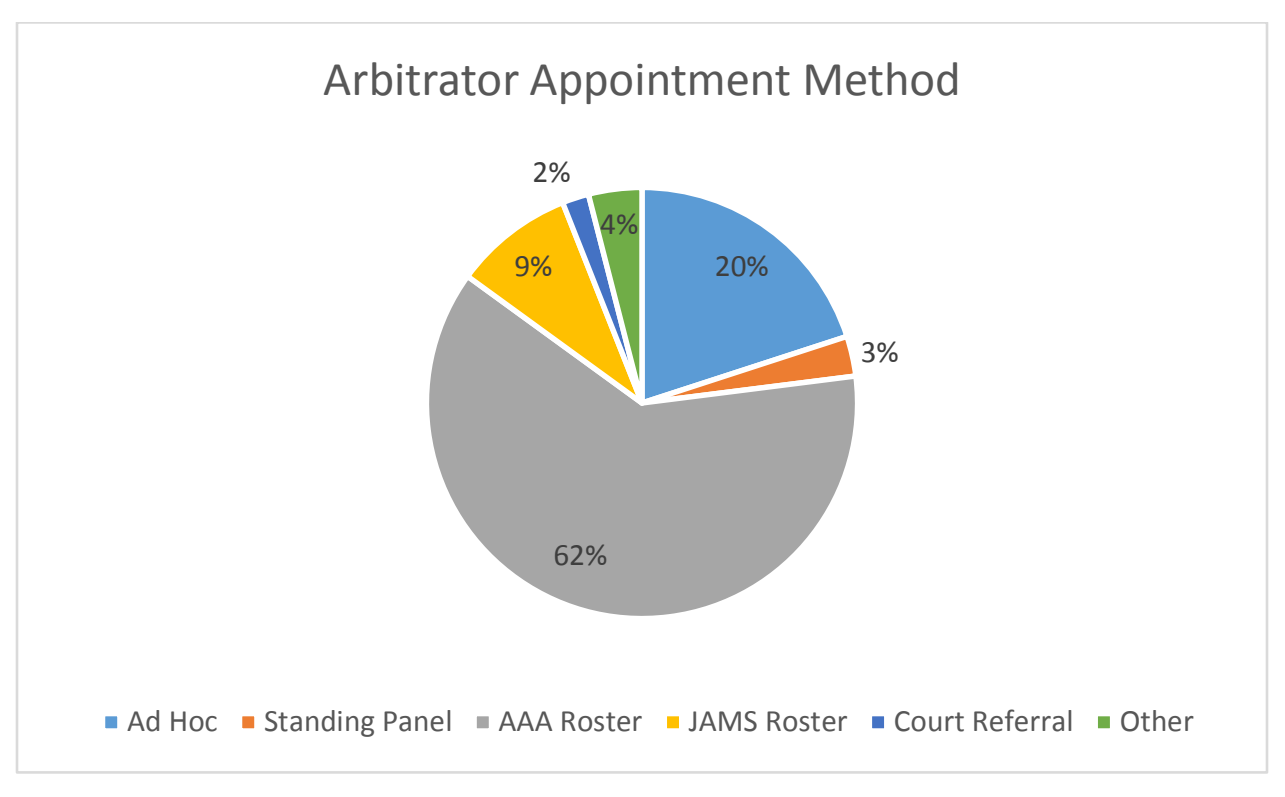


Bibliography

Bemmels, Brian. 1988a. The Effect of Grievants' Gender on Arbitration Decisions. Industrial and Labor Relations Review 41: 251-62.

Bemmels, Brian. 1988b. Gender Effects in Discipline Arbitration: Evidence from British Columbia. Academy of Management Journal 31: 699-706.

Bemmels, Brian. 1990. Arbitrator characteristics and arbitrator decisions. Journal of Labor Research 11: 181-91.

Bigoness, William J., and Phillip B. DuBose. 1985. Effects of Gender on Arbitrators' Decisions. Academy of Management Journal 28(2): 485-91.

Bingham, Lisa B., and Debra J. Mesch. 2000. Decision making in employment and labor arbitration. Industrial Relations: A Journal of Economy and Society 39(4): 671-694.

Block, Richard N., and Jack Stieber. 1987. The impact of attorneys and arbitrators on arbitration awards. Industrial and Labor Relations Review 40(4): 543-555.

Caudill, Steven B., and Sharon L. Oswald. 1993. A Sequential Selectivity Model of the Decisions of Arbitrators. Managerial and Decision Economics 14(3): 261-267. 
Clermont, Kevin J., and Stewart J. Schwab. 2004. How Employment Discrimination Plaintiffs Fare in Federal Courts. Journal of Empirical Legal Studies 1(2): 429-458.

Colvin, Alexander J.S., and Mark Gough. 2015. Individual Employment Rights Arbitration in the United States: Actors and Outcomes. Industrial and Labor Relations Review 68(5): 10191042.

Colvin, Alexander J.S. 2011. An Empirical Study of Employment Arbitration: Case Outcomes and Processes. Journal of Empirical Legal Studies 8(1): 1-23.

Colvin, Alexander J. S. 2007. Empirical research on employment arbitration: Clarity amidst the sound and fury. Employment Relations and Employment Policy Journal 11(2): 405-448.

Colvin, Alexander J.S. 2003. Institutional Pressures, Human Resource Strategies and the Rise of Nonunion Dispute Resolution Procedures. Industrial and Labor Relations Review 56(3): $375-92$.

Clermont, Kevin M., and Stewart J. Schwab. 2009. Employment Discrimination Plaintiffs in Federal Court: From Bad to Worse. Harvard Law \& Policy Review, 3(1): 103-132.

Clermont, Kevin M., and Stewart J. Schwab. 2004. How employment discrimination plaintiffs fare in federal court. Journal of Empirical Legal Studies 1(2): 429-458. 
Edelman, Lauren B., Linda H. Krieger, Scott R. Eliason, Catherine R. Albiston, and Virginia Mellema. 2011. When organizations rule: Judicial deference to institutionalized employment structures. American Journal of Sociology 117(3): 888-954.

Edelman, Lauren B., Christopher Uggen, and Howard S. Erlanger. 1999. The endogeneity of legal regulation: Grievance procedures as rational myth. American Journal of Sociology 105(2): 406-454.

Edelman, Lauren B. 1992. Legal ambiguity and symbolic structures: Organizational mediation of civil rights law. American journal of Sociology 97(6): 1531-1576.

Estreicher, Samuel. 2001. Saturns for Rickshaws: The Stakes in the Debate Over Predispute Employment Arbitration Decisions. 16 Ohio State Journal of Dispute Resolution 559564.

Gough, Mark. 2014. The High Costs of an Inexpensive Forum: An Empirical Analysis of Employment Discrimination Claims Heard in Arbitration and Civil Litigation. Berkeley Journal of Employment and Labor Law 35(2): 91-112.

Gough, Mark. 2016. Employment Lawyers and Mandatory Employment Arbitration: Facilitating or Forestalling Access to Justice. Advances in Industrial Relations 16(4): 133-157. 
Guthrie, Chris., Jeffrey J. Rachlinski, and Andrew J. Wistrich. 2007. Blinking on the bench: How judges decide cases. Cornell Law Review 93(1): 1-44.

Hirsh, Elizabeth C., and Sabino Kornrich. 2008. The context of discrimination: Workplace conditions, institutional environments, and sex and race discrimination charges. American Journal of Sociology 113(5): 1394-1432.

Klaas, Brian S., Mahony Douglas, and Hoyt N. Wheeler. 2006. Decision-Making about workplace Disputes: A policy-Capturing Study of Employment Arbitrators, Labor Arbitrators, and Jurors. Industrial Relations: A Journal of Economy and Society 45(1): 68-95.

Lamare, Ryan J. and David Lipsky. 2014. Employment Arbitration in the Securities Industry: Lessons Drawn from Recent Empirical Research. Berkeley Journal of Employment and Labor Law 35(2): 113-133.

Lipsky, David B., Ronald L. Seeber, and Ryan J. Lamare. 2010. “The Arbitration of Employment Disputes in the Securities Industry: A Study of FINRA Awards, 19862008,” Dispute Resolution Journal, vol. 65, no. 1 (February-April), pp. 12 and 54-61

Lipsky, David B., Seeber L. Ronald, and Richard D. Fincher. 2003. Emerging Systems for Managing Workplace Conflict: Lessons from American Corporations for Manager and Dispute Resolution Professionals. Industrial and Labor Relations Review. 
Lipsky, David B., Seeber, Ronald L. 2004. The Ascendancy of Employment Arbitrators in U.S. Employment Relations: A New Actor in the American System? British Journal of Industrial Relations 44(4):719-756.

Lipsky, David B., Ryan J. Lamare, and Abishek Gupta. 2013. The Effect of Gender on Awards in Employment Arbitration Cases: The Experience in the Securities Industry. Industrial Relations 52(s1): 314-342.

National Academy of Arbitrators (NAA). 2012. NAA Membership Guidelines. (http://naarb.org/member_guidelines.asp. Accessed on 6/12/201.

Nielson, Laura B., Robert L. Nelson, and Ryon Lancaster. 2010. Individual Justice or Collective Legal Mobilization? Employment Discrimination Litigation in the Post Civil Rights United States. Journal of Empirical Legal Studies 7(2):175-201.

Pfeffer, Jeffrey. 1977. The ambiguity of leadership. Academy of Management Review 2(1): 104112.

Sandefur, Rebecca L. 2015. Elements of professional expertise: Understanding relational and substantive expertise through lawyers’ impact. American Sociological Review 80(5): 909-933. 
Schwab, Stewart J., and Theodore Eisenberg. 1987. Explaining Constitutional Tort Litigation: The Influence of the Attorney Fees Statute and the Government as Defendant. Cornell Law Review 73(4): 719-784.

Scott, Clyde, and Elizabeth Shadoan. 1989. The effect of gender on arbitration decisions. Journal of Labor Research 10(4): 429-436.

Seeber, Ronald L., and David B. Lipsky. 2006. The ascendancy of employment arbitrators in US employment relations: A new actor in the American system?. British Journal of Industrial Relations 44(4): 719-756.

Segal, Jeffrey A., and Harold J. Spaeth . 2002. The Supreme Court and the attitudinal model revisited. Cambridge University Press.

Sherwyn, David, Samuel Estreicher, and Michael Heise. 2005. Assessing the Case for Employment Arbitration: A New Direction for Empirical Research. Stanford Law Review 57(5): 1557-1591.

Spaeth, Harold J., and Jeffrey A. Segal. 1999. The US Supreme Court Judicial Data Base: Providing New Insights into the Court. Judicature 83(5): 228-235. 
Steffensmeier, Darrell., and Chris Hebert. 1999. Women and men policymakers: Does the judge's gender affect the sentencing of criminal defendants?. Social Forces 77(3): 11631196.

Stone, Katherine V.W. 1996. Mandatory Arbitration of Individual Employment Rights: The Yellow Dog Contract of the 1990’s. Denver University Law Review 73(4): 1017-1050.

Thornton, Robert J., and Perry A. Zirkel. 1990. The consistency and predictability of grievance arbitration awards. Industrial and Labor Relations Review 43(2): 294-307.

Zirkel, Perry A. 1983. Building an Approporiate Education from Board of Education v. Rowley: Razing the Door and Raising the Floor. Maryland Law Review 42(3): 466-495. 